\title{
Decolonizing Siberian Minds
}

\author{
MATTHEW P. ROMANIELLO
}

$\mathrm{R}$ ussian imperialism continues to leave a strong imprint on indigenous cultures across Siberia, and throughout the Russian Federation and the post-Soviet republics. Imperialism is invasive and persistent, and it might be impossible to escape its consequences. In 1986, African novelist and postcolonial theorist Ngũgĩ wa Thiong'o published his influential essay collection, Decolonising the Mind: The Politics of Language in African Literature. One of his arguments is that no postcolonial subject could be free from the constraints of imperialism until she or he succeeded in freeing the mind from the trap of an imposed (and foreign) language. Ngũgĩ's experience was based on his own life growing up in Kenya, but his lesson is as applicable to Siberia as it is for East Africa. For indigenous Siberians, language and education are at the forefront of the ongoing postcolonial struggle to maintain their cultural identities in modern Russia.

Education and language are the central issues in three articles in this issue of Sibirica, each based on extensive fieldwork in the region. Erzhen Khilkhanova examines the attitudes of both Buriat and Russian students toward language and identity, based on her case study from the Republic of Buriatiia. Alena Ivanova's article discusses identity construction among the children of indigenous peoples of Siberia and the Far East. Her particular focus is on the impact of curriculum development on modern education practices. Finally, Maria Pupynina and Yuri Koryakov have produced an extensive study of spoken-language shifts among the Chukchi community, which is separated in three different Russian regions. Together these articles offer a multivalent approach to the important issue of maintaining cultural identity in the face of long-term colonial pressures from the Russian government. While each author is aware of the struggle of these various indigenous groups to maintain their distinct identities and maintain their language, it is a story that resonates with the struggles in postcolonial Africa to "decolonize" their minds and education systems from the colonial era.

Art Leete's article on the depiction of Finno-Ugric peoples in eighteenth- and nineteenth-century ethnographic studies of the Russian 
Empire may appear as an outlier to the postcolonial struggles of the other articles, but this is far from the case. Leete has produced a study that demonstrates the ways in which the Russian government and its officials began the process of constraining indigenous culture. His article demonstrates the negative depictions of Finno-Ugric cultures having deep roots, which creates a systemic pressure on these groups from state authorities. Colonialism was a long-term process, which is why the struggle to maintain independent cultural identities is so difficult, as the contemporary articles reveal.

Bringing scholars together from multiple fields in a common purpose is the strength of an interdisciplinary journal such as Sibirica. We look forward to continuing to break new ground in our future issues. 